\title{
SubURBAN RENEWAL. Perspectives from Belgian, Danish and FRENCH CASES
}

Renovación suburbana.

Perspectivas a partir de casos belgas, daneses y franceses

\author{
Marion Serre \\ Ecole Nationale Supérieure d'Architecture de Marseille, \\ ENSA-M, France \\ mjo.serre@gmail.com
}

Rémy Vigneron

Lab InVivo, France

remy.vigneron@vivantes.fr

\section{Oswald Devisch}

Hasselt University, Belgium

oswald.devisch@uhasselt.be

\author{
Majken Toftager Larsen \\ Roskilde University, Denmark \\ matola@ruc.dk
}

\section{Ion Maleas}

Ecole Nationale Supérieure d'Architecture de Marseille, ENSA-M, France ionmaleas@gmail.com

\begin{abstract}
This paper examines the change in the perception of the suburban from an inherently non-sustainable territory to one with environmental, social and architectural potential through a comparative analysis of the suburban in three European countries: Belgium, France and Denmark. The approach identifies urban, architectural, social and environmental constants and variables in each country in order to better illustrate the reasons for and nature of this shift of perception.
\end{abstract}


The article begins with a comparative insight into the legal contexts and urban policies that have favored or limited suburban development. This review highlights how the increasing focus on sustainable development has introduced the concept of suburban transformation as an integral part of the 'urban sustainability' discourse. Several case studies of renewal initiatives in the three countries are then examined.

KEYWORDs: suburbanization, urban renewal, planning policies, sustainability.

RESUM: Aquest article examina el canvi de percepció del suburbà d'un territori inherentment no sostenible cap a un amb potencial ambiental, social i arquitectònic a través d'una anàlisi comparativa de l'espai suburbà en tres països europeus: Bèlgica, França i Dinamarca. L'aproximació identifica les constants i variables urbanes, arquitectòniques, socials i ambientals a cada país per a il·lustrar millor els motius i la naturalesa d'aquest tipus de percepció.

El text s'enceta amb una mirada comparativa dels contextos legals i polítiques urbanes que han afavorit o limitat el desenvolupament suburbà. Aquests punts destaquen com l'auge creixent del desenvolupament sostenible ha introduït el concepte de transformació suburbana com una part integral del discurs de la «sostenibilitat urbana». Són examinats diversos estudis de cas d'iniciatives de renovació dins els tres països.

Paraules Clau: suburbanització, renovació urbana, polítiques de planificació, sostenibilitat.

RESUMEN: Este artículo examina el cambio de percepción de lo suburbano de un territorio inherentemente no sostenible hacia uno con potencial ambiental, social y arquitectónico a través de un análisis comparativo del espacio suburbano en tres países europeos: Bélgica, Francia y Dinamarca. La aproximación identifica las constantes y variables urbanas, arquitectónicas, sociales y ambientales en cada país para ilustrar mejor los motivos y la naturaleza de este tipo de percepción.

El texto comienza con una mirada comparativa de los contextos legales y políticas urbanas que han favorecido o limitado el desarrollo suburbano. Estos 
puntos destacan cómo el auge creciente del desarrollo sostenible ha introducido el concepto de transformación suburbana como una parte integral del discurso de la «sostenibilidad urbana». Son examinados varios estudios de caso de iniciativas de renovación dentro de los tres países.

Palabras clave: suburbanización, renovación urbana, políticas de planificación, sostenibilidad.

\section{Introduction}

Uuburbanization, and more precisely the increasing development of resDidential subdivisions, are at the core of many current debates on broad scientific and political levels and are informing concerns on how to reinvent planning models to deal with existing territories. This issue is mainly dominated by discussions on the problems of urban sprawl. Waste of land, the encroachment of building on agricultural and natural land, increased infrastructure and network costs, the intensification of motorized transportation, individualism or a lack of urbanity are now commonplace (Newman \& Kenworthy, 1999; Phelps \& Wu, 2011; PUCA, 2011; Pinson, 2017). The recurrence of these assessments has actively contributed to positioning the fight against urban sprawl as a central twenty-first century issue. However, beyond these negative perspectives, other investigations have revealed the potential of suburbs from different points of view-ecological (Frileux, 2013), social (Dodier, 2012; Lambert, 2015), architectural and urban (Bonnet, 2016) - that compel us to transcend the traditional urban-suburban dichotomy (Tzaninis $\&$ Boterman, 2018). Both these positions are informing concepts of suburban renewal, which has emerged as a central issue of sustainable development in Europe.

In light of these changes, this paper examines the shift in the perception of the suburban from an inherently non-sustainable territory to one also understood to have environmental, social and architectural potential. It explores how the academic and professional discourse has mobilized the concept of 
'sustainability' in the suburban renewal debate. The paper also investigates the potential of a more collaborative approach to suburban renewal as a way of addressing such sustainability concerns.

To this end, we present a comparative analysis of the suburban territories in three European countries: Belgium, France and Denmark. This comparative review is based on an analysis of selected scientific papers and the evolution of the laws in the three countries. First, this comparison provides insight into the urban policies that have favored or limited suburban development since the end of the nineteenth century. The second section explains how the increasing focus on sustainable development has introduced the concept of suburban transformation. A range of initiatives is then examined, some of which are selected to elucidate different ways of implementing renewal driven by citizens, associations, professionals or public institutions. These examples illustrate the potential that can be found within European suburban environments. They offer opportunities to rethink the urban system and urban expansion from a collective and collaborative perspective, and highlight the challenges of sustainable urban expansion models.

\section{The historical trajectories shaping Belgian, French and Danish suburbs}

Far from an ignored and misunderstood phenomenon, suburbanization is a subject of multidisciplinary research that has been observed, described and analyzed for over fifty years through both qualitative and quantitative approaches. Urban sprawl in France, Belgium and Denmark has been shaped through the interplay of political choices, and public and private actions, all of which need to be understood to consider the future of residential subdivisions.

\section{I.I Growth policies for unrestricted expansion}

In most of Europe extensive urbanization began in the nineteenth century (Guerrand, 1987; Hall \& al. 1991; Sverrild, 2016). Against the backdrop of 
the industrial revolution and aspirations to improve housing conditions in overpopulated cities, the single-family house became the symbol of a new urban order seeking to invent a compromise between the rural and urban. Belgium, France and Denmark each have their own specific historical trajectories that illustrate this general trend.

At the end of the twentieth century, legislative initiatives in all three countries led to the widespread development of suburban neighborhoods around major cities (De Decker \& Dewilde, 2010; Dragsbo, 2008; Puissant, 2008). This first generation of residential neighborhoods formed a model of urbanization mainly consisting of detached single-family houses, developed spontaneously, mostly around railroad stations and other mobility infrastructures.

With the interwar period, the single-family home model of urbanization began to generate political interest. New laws established financial incentives for homeownership and promoted new construction (Schreurs et al., 1999; Van de Weijer, 2014; Fourcaut, 2000; Dragsbo, 2008; Lind \& Møller, 1996). During this period an ideological divide began to form in the housing market between collective public housing and individual private housing, leaving an imprint of socio-spatial segregation on the suburban landscape (Sverrild, 2016; Dezès, 2001). As Manuel Castells points out, "the suburban world of European cities is a socially diversified space" (1996: 432), thus calling for understanding of the social contingency of place. However, as most development was inspired by Ebenezer Howard's garden city model, the residential subdivisions across Europe share many characteristics, such as blocks with green open courtyards, terraced houses and garden suburbs with single-family houses (Hall, 1991).

Postwar, the city was adapted to industrialization through the generalization of a mass model that came directly from the United States. In Belgium, the rising demand for land resources stimulated the construction of single-family houses. The house-building boom occurred without any spatial planning (De Meulder et al., 1999). This led to dispersed private dwellings, ribbon development along city access roads and unplanned, dispersed allotment schemes, the most common way to free up land for new house construction (De Decker, 2008). In the mid-1960s, the French government started to promote homeownership with subsidized mortgages (Driant, 2015). A number of national 
and international competitions were intended to revive French enthusiasm for homeownership. ${ }^{1}$ This period was marked by a change in social housing production which abandoned the modernist high-rise model $^{2}$ and experimented with subsidies for single-family houses and homeownership. ${ }^{3}$

In contrast to the trends in France and Belgium, Denmark set environmental priorities immediately after the war, requiring that special zones for urban development should be defined round the larger towns to prevent uncontrolled urban growth and to preserve farmland and recreational resources (Gaardmand, 1993; Hall, 1991:33). However, the 1960s were still marked by the construction boom, with a significant increase in the number of detached and semi-detached houses in preference to collective housing (Hall, 1991:39). The high demand for residential developments during the 1960s and 1970s resulted in large subdivisions all over the country. These residential subdivisions were typically designed around homogenous road systems and grid structure parcels, with standard houses, and later received much architectural criticism for their mono-functional character (Sverrild, 2016; Kvorning, 2012; Bech-Danielsen, 2013).

In all three countries, history has shown a strong and continuous popular demand for single-family homes across different social groups (Dragsbo, 2008; Jensen, 2006; Damon, 2017). ${ }^{4}$ The state played an undeniable role in this remarkable twentieth-century phenomenon (Ascher, 1995; Hirt, 2007), when suburbanization was both a desired and promoted phenomenon. Whether controlled or not, this political and urban dynamic has had some alarming

1. For example, in 1967, "Villagexpo" was an experiment in a horizontal joint ownership of nearly 330 single-family houses designed to show potential housing solutions to future homeowners.

2. In 1973, minister Guichard's memorandum put an end to the modernist high-rise buildings by prohibiting the construction of complexes of more than 500 dwellings

3. In 1969, the international competition for single-family dwellings led to the construction of 70,000 "chalandonnettes" (in reference to the minister that led this initiative, Albin Chalandon).

4. In contemporary societies_characterized by risk (Beck, 1992)—homeownership represents relative stability. Ownership is also perceived as a vector of social valorization, and offers the middle class some social insurance against rising social uncertainties (Jaillet, 2004; Djefal \& Eugène, 2004). 
consequences, ${ }^{5}$ and although it was expected to slow down after the first oil crisis, this deceleration has yet to actually happen. Urban sprawl in Europe takes, on average, 1000 square kilometers of land each year (European Environment Agency, 2016). An area equivalent to the size of Belgium is expected to be artificialized within the next 20 years, as urban sprawl increases rapidly from one decade to another. This phenomenon poses questions for the sustainability of contemporary models of urban expansion.

\section{I.2 The sustainable turn of spatial planners}

The classic definition of sustainable development from the Bruntland report is a "development that meets the needs of the present without compromising the ability of future generations to meet their own needs" (1987). Since then, this notion has become political, philosophical, and militant; it has been appropriated by numerous actors, following different agendas, to become more a slogan than a reality. In consequence, the notion of sustainable development has been as controversial as it has been successful (Deléage, 2013).

To address the challenges of sustainable planning, European governments have issued numerous injunctions in urban planning procedures, many of which aim to limit urban sprawl and promote urban renewal. As a result, renewal initiatives calling for sustainable transition proliferated at the end of the last century. These initiatives make clear that there is "both an enormous necessity and a grand opportunity to seek new behaviors, institutions, policies (public and private), technologies, urban forms, environmental management (water, wastes, air quality), and infrastructure configurations moving urban areas toward sustainability. Now is the time to bring together the science and technology of habitability, efficiency, and environment with the practice of planning, building, and financing the cities of tomorrow" (Clark, 2001:1061).

In France, the Voynet law (1999) marked the beginning of reflections on both participatory democracy and the fight against urban sprawl. The law decentralized state action, giving more power and freedom of initiative to

5. As evidenced by the founding documents for sustainable development: The Meadows Report (1972), The Brundtland Report (1987) and The Rio Summit (1992). 
municipalities for land-use and planning projects. These orientations were further strengthened by the SRU law (2000), which denounced the separation of urban functions and redefined the rules of urban planning to promote the renewal of 'the city on the city'. Nevertheless, cities continued to expand (Piron, 2011), and more laws were passed in an effort to limit sprawl. ${ }^{6}$

In Belgium, federalization brought about a gradual devaluation of powers from the state level to communities and regions. In Flanders, the Spatial Structure Plan, introduced in 1997, raised citizens' awareness that land is a scarce resource. At the same time, the Flemish government approved so many amendments that the suburbanization process has continued unhalted, although it is now working on a new spatial planning policy that will limit greenfield development from 2040 onwards.

Densification and restructuring of the suburbs have also been discussed within Danish academic and political circles over the last thirty years, and interest continues to grow (Dragsbo 1988, Lind \& Møller, 1996; Jensen, 2006, Sverrild, 2016). A significant shift towards more concentrated urban development on a national level was introduced by the 1992 Planning Act, which stated that most urban growth should be contained within existing urban borders or areas already designated for urban development. Preparing the ground for raising the density of existing residential subdivisions built between 1960 and 1980 has also been a concern for the Ministry of Housing, Urban and Rural Affairs. Danish municipalities have long had relatively high autonomy in urban planning matters (zoning, plot ratios, etc.) (Andersen \& Hovgaard 2003). Several municipalities are currently also working with various planning initiatives to promote densification of existing residential subdivisions (Richner \& Ibsen, 2016).

Whereas the suburb was originally seen as a solution to the environmentally and socially degraded city, the qualities of the dense and multifunctional city are increasingly imposed as an ideal for restructuring suburbs, although it is also recognized that the suburb must be restructured on its own terms (Bech-Danielsen, 2013). Sustainable planning principles have been incorpo-

6. The ENE law (2010) was intended to limit urbanization to sectors connected to mass transportation. The ALUR law (2014) made construction of new building in already built-up areas compulsory and revoked the land use ratio 
rated into national policies, a trend that is also reflected in local planning documents for suburban territories. The initial legislative approach to incentivize adoption of these principles had little effect on the ground, however. By 2010, legislators had adopted a more coercive approach by introducing quantifiable goals that would drive the creation of operational tools. This political context is favorable to the development of multiple actions (urban projects, research programs, pilot schemes, etc.) whose purpose is to test hypotheses aiming at suburban renewal.

\section{The suburban as a core element of sustainability: from anti- urban to a territory with potential}

At the same time, suburbs do change. People renovate, expand, and move, sometimes less sustainably, but other times in a more sustainable direction. As cities continue to expand, residential subdivisions have attracted growing professional and scientific interest over the last decade in the three countries observed. Municipalities are looking for new solutions to deal with these disconnected urban spaces that empty their city centers of vibrant young families, or to diversify their housing stock and urban environment to attract new residents. Scientists, urban planners and other professionals engaged in suburban development are facing the challenge of reinventing their practices to transform suburbs. Dismissed in common representations and practically ignored in policies, these inhabited spaces are gradually being re-staged (Sverrild, 2016; Dunham-Jones, 2011). Now seen as areas of resources, citizen expression and invention, they are emerging as a potential support for a new urbanism that engages inhabitants more widely to reinvent traditional structures of governance. In this section of the paper, a selective bibliographical review highlights the interdisciplinary discourses concerning the environmental, social and spatial potential of suburbia.

The suburban landscape and suburban lifestyle ideal have long been subject to scientific, architectural and cultural critique. Suburban territories were once understood and portrayed as anti-urban (Krim, 1992; Stevenson, 2003). There are three recurrent themes in these critiques: the environmental effects of urban sprawl, the social homogeneity and individualism of sub- 
urban residents, and the lack of architectural quality and urban form. These critiques determined a stereotyped and one-dimensional view of the suburbs that does not take into account specific places and histories (Phelps and $\mathrm{Wu}$, 2011; Sverrild, 2016; Hesse \& Siedentop, 2018). Also, they tend to foster an understanding of these as fixed spaces that avoid any restructuring initiatives. However, these themes must be further scrutinized in order gain a fuller grasp of the contradictions and tensions related to residential subdivisions. Ultimately this can lead to a better understanding of how residential subdivisions can be regarded as dynamic spaces with the potential to reveal contemporary changes in urban practices and lifestyles.

As the Canadian geographer and historian Richard Harris points out, the conversion of natural land into a suburban structure is not a one-time event, a simple shift into a fixed spatial structure that cannot be changed. Rather, he claims suburban development is a gradual and ever evolving process, "Suburban land does not just lie between the country and the city, but in the long view each parcel undergoes that transition begging us to view it historically" (Harris, 2013: 33). ${ }^{7}$ Many other researchers have also broken away from the urban-suburban divide, attempting to define the suburban through terms such as the diffused city ${ }^{8}$ (Indovina, 1990), the emerging city ${ }^{9}$ (Chalas \& DuboisTaine 1997), or the in-between city ${ }^{10}$ (Sieverts, 2003). What these authors have in common is their positive approach and a determination to describe this type of territory in its own right, by identifying its unique environmental, social and spatial characteristics (Charmes 2015a; 2015b).

7. He goes on: Guiding that evolution, almost everywhere is a land market. Not a market, because markets vary greatly in character, never corresponding to an ideal. But a market nontheless, with private land tenure, negotiated prices and government regulation. In these terms suburban land is converted from rural to urban allocated to users and in time redeveloped. The operations are rarely visible, sales billboards being an exception, but it is restless markets that make and remake the suburbs (Harris 2013: 33)

8. Translation of "La città diffusa", Francesco Indovina (1990)

9. Translation of the term used in the book "La ville émergente", Chalas \& Dubois-Taine (1997)

10. Translation of "Zwischenstadt", as used by Thomas Sieverts in 1997 


\section{I Environment and transportation: the great paradox of having it better!}

Environmental criticism is mainly based on the waste of land, artificialization of the soil, predominant car use exacerbating the greenhouse effect, energy expenditure due to the remoteness from urban cores (water, electricity, etc.). The strength of these criticisms has often overshadowed one of the main qualities of residential subdivisions: living 'in between city and countryside' to benefit from urban services while surrounded by nature.

As early as the 1960s, French sociologists showed that the need for nature had driven some people to settle in residential subdivisions (Lefèbvre, 1966: 16). This phenomenon raises a great paradox between the search for a better living environment (less polluted, more 'green and natural') and the degradation of this same environment caused by the artificialization of the soil and pollution generated by car use (Dodier, 2012: 17). The benchmark for the critique is that the suburbs must be restructured to mimic the more urban qualities of the central cities and reflect an ideal of new urbanism. A curious ambition, Bech-Danielsen notes, as many new residential areas in the central cities are designed with typically suburban recreational qualities in mind (Bech-Danielsen, 2013). ${ }^{11}$ Several researchers are now highlighting the need to 'take the best of' the existing qualities of the suburban areas, for instance, by emphasizing the ecological potential of private gardens (Frileux, 2013). At the environmental level, the debate tends towards the revalorization of residential subdivisions. The evident interest in suburban qualities in central city housing areas also suggests that the single-family house with a private garden continues to offer lifestyle qualities that must be taken into consideration in the restructuring process. Just as incorporating landscape qualities serves an important function in the ecological restructuring of the city, the existing ecological functions, and how they can be balanced with the obvious need to counter urban sprawl, must be contemplated.

11. New housing areas are being built in towns and cities with lawns on roofs, and views over recreational areas (both green and blue) - and the smell of barbeques provides an urban atmosphere on a warm summer evening (Bech-Danielsen 2013: 8) 


\subsection{Social diversity and the debate on individualism}

Social criticism is based on several aspects. Among these, 'petty bourgeois individualism' (Magri, 2008), social grouping (Donzelot, 2009) or even the dormitory effect are stereotypical and stigmatizing representations of residential subdivisions and their inhabitants. Some authors even point to a dystopian image of the suburb as representing physical and social monotony and its purported destructive influence on civic responsibility and the dissolution of social structures (Sverrild, 2016). In response to this predominant trend, researchers such as Berger et al. question the stereotypical image of the socially isolated inhabitant and show that there are in fact multiple forms of sociability (Berger et al., 2007). In her recent book Radical Suburban, Amanda Kolson Hurley traces a rich history of experimental residential and political projects in American suburbia (2019). Researchers challenging these stereotypes have shown that there is no single suburban reality, but rather a wide range of areas, living conditions, spatial practices, and forms of mobility (Dodier, 2012; Charmes et al., 2014: 85; Hurley, 2019; PUCA, 2015; De Decker \& Meeus, 2013).

In a similar vein, Lambert's analysis reveals a diverse homeowner profile: retired people, families who have moved out of the city, young professionals, etc. For all of them, access to property is a form of social advancement, but one that is often very different to the general image of the 'petty bourgeois' residential subdivisions (Lambert, 2015). Sverrild also identifies a great social diversity among suburban residents and shows how site-specific agents and circumstances have led to quite different trajectories of development which are now reflected in different demographic, political and cultural conditions across suburbs (Sverrild, 2016). Thus, these empirical analyses seek to overcome the 'for or against' division, and avoid favorable or unfavorable overviews of this residential model and its inhabitants by deciphering its multiple socio-spatial realities.

\subsection{Architecture and urban form}

Architectural and urban criticism has sought to denounce the spatial disorders that arise from residential subdivisions which have often been opposed 
to the rationalism and functionalism of collective housing (Le Corbusier, 1971). Although residential subdivisions may be the result of piecemeal town planning (Bauer, 1979; Vanier 2011), the debate has evolved and is going beyond the 'anti-residential subdivisions' ideology (Marchal \& Stébé, 2017). From being an almost invisible structure of the urban landscape in Denmark, the suburbs are increasingly seen as part of the cultural heritage. Political and professional statements revere suburban areas-including residential subdivisions - as important architectural expressions of the welfare society (Kvorning, 2012; Bech-Danielsen, 2013; Sverrild, 2016). Indovina points out the absence of a dominating center in the diffused city (Charmes, 2015c; Indovina, 1990); Sieverts' in-between city recognizes the new characteristics (spatial, economic, historical, etc.) of a form of regional scaled urbanization, producing a territory that is neither urban nor rural (2003); and Chalas and Dubois-Taine define exemplary figures (territory city, nature city, polycentric city, etc.) as uniquely defining of their emerging city (1997). Among the suburban social experiments presented in Hurley's work, several are underpinned by innovative urban and architectural models, such as the New Deal garden cities of the $30 \mathrm{~s}$ and $40 \mathrm{~s}$, or the example of The Architects Collaborative (TAC), which included Bauhaus school founder Walter Gropius, that in the 50s designed and lived in Six Moon Hill, a progressive modernist suburb in Lexington, Massachusetts (Hurley 2019). In more recent examples Ellen Dunham-Jones presents a number of innovative renewal projects taking place in underachieving commercial strips or underused parking lots in suburban America (2011). Indeed, residential subdivisions have gradually been recognized no longer as the products of a symptomatic urbanization process, but as one of the forms of today's urbanization.

Through these scopes, residential subdivisions are increasingly seen as dynamic spaces, spaces that are continuously being reproduced (Lefebvre, 1974), and spaces revealing contemporary changes in the urban mode of production and lifestyles (Dodier, 2012; PUCA, 2014-2017). 


\section{Examples of renewal initiatives}

Based on the potential of the suburban described above, we now present a number of specific case studies from the three countries examined. The case studies and the practices presented were chosen on the basis of their effort to address social challenges (diversity, affordability, inhabitant practices, etc.), environmental challenges (densification, energy consumption, etc.) and spatial challenges (architectural form, functional diversity, professional practices, etc.). These renewal initiatives provide topical examples of the suburban as a resource, in which diverse actors (inhabitants, citizen associations, urban professionals, local governments, etc.) and innovative practices demonstrate this potential.

\section{I. Co-housing: an alternative to the simple suburban house?}

Co-housing is known as a collective housing model, based on the combination of private homes organized around collective indoor and outdoor facilities and spaces shared by residents. This model allows groups of citizens to conceive, create and manage their housing collectively. These projects are usually based on strong ideas such as community, sharing, solidarity, environmental sensitivity, etc. (Chiodelli \& Baglione, 2013; Lietaert, 2010). At its core, co-housing relies on participatory processes, thus producing a socially vibrant housing model (Marcus, 2000; Williams, 2005; Lietaert, 2010; Tummers, 2010a, 2010b).

Denmark has a long tradition of co-housing (bofcellesskab) and was the first country to experiment with such concepts. The first attempts started in 1964 and 1972 in the greater area of Copenhagen, marking the beginning of a movement that quickly spread to the Netherlands and Sweden (Lietaert, 2010; Williams, 2005). These forms of Danish co-housing are diverse and range from small collectives of people sharing a large apartment or a house, to bigger building complexes organized around collective living with varying degrees of shared living. In France, the history of co-housing goes back to the movement des Castors, conceived after the Second World War. The ALUR law (2014) officially recognizes and facilitates co-housing operations, guaranteeing stable processes and financial protection for stakeholders. In Belgium, the co-housing debate in the Flemish government began in 2006 when two 
politicians, Vera Dua and Mieke Vogels, proposed a new decree calling for greater attention to collective forms of dwelling such as co-housing (co-ownership, cooperatives, co-housing for/by the elderly, ${ }^{12}$ etc.). However, to this day there is a legal void concerning co-housing in Belgium and emerging projects are inscribed in various other legal definitions (Habitat Groupé-Solidaire, 2017).

The contexts and morphological characteristics of co-housing projects vary greatly (Tummers 2010a), although co-housing has been greatly influenced by the residential subdivision model characteristic of the twentieth century European urbanization model (McCamant et al., 1994; McCamant \& Durrett, 2011; Field, 2004; Hanson \& Hanson, 2004). Often built in suburban areas, the co-housing model tends to share morphological characteristics with residential subdivisions such as low-rise buildings and a significant presence of nature (Williams, 2005).

Co-housing relates to the renewal of residential subdivisions in the sense that it tends to be much denser and creates vibrant spaces due to shared amenities. Although co-housing has generated "substantial attention for 'self-managed accommodation'” (Tummers, 2010a: 66), its application continues to face challenges, and it still accounts for a very low percentage of the housing stock within each country. ${ }^{13}$

\subsection{Affordable housing initiatives}

In postwar France, residential subdivisions started to become an affordable housing resource thanks to citizen involvement. Through citizen associations, houses were renovated or built in suburbs and newcomers were gradually integrated into already existing neighborhoods. In 1990, the Besson Law ${ }^{14}$

12. http://www.abbeyfield.be/

13. In Denmark, the Bofællesskab.dk association has around 131 co-housing projects, of which 20 are under construction. This stock represents $1 \%$ of the country's total housing stock (Kristensen, 2007; Pedersen, 2015). In Belgium, there are currently 98 co-housing projects, as documented by the association of co-housing in the regions of Wallonia and Brussels (Habitat Groupé, 2017b). In France, in 2017, the coordinator of co-housing associations had 480 projects, of which 132 are completed and another 78 are under construction, while the rest are in the project stage (Habitat Participatif France, 2019).

14. https://www.legifrance.gouv.fr/affichTexte.do?cidTexte=JORFTEXT000000159413 
recognized the active role that several established citizen associations had played in the social housing market. This law succeeded in professionalizing these associations, also called 'social micro-landlords' (Primard \& Touati, 2015 ), especially in securing their financial viability (Driant 2015). It also emphasizes the concept of social integration through housing, which has since become the focus of such citizen associations (Driant, 2015; Primard \& Touati, 2015; Stébé, 2016).

Solidarités Nouvelles pour le Logement ${ }^{15}$ (SNL) is one of these social micro-landlords (Primard \& Touati 2015) active in the Paris metropolitan area. According to recent research, SNL stands out as a systematic producer of affordable housing (Touati, 2015; Driant, 2015). Its projects, each of which provides up to twelve housing units, usually involve acquiring an existing single-family house and transforming it through rehabilitation, extension, subdivision or the construction of completely new units. Anastasia Touati points to the active role that SNL plays in soft densification of residential subdivisions in the Parisian suburbs (Touati, 2015).

Citizen participation is one of the basic conditions for SNL's involvement in a project. Each project is accompanied by volunteer local residents who are actively engaged in local housing market prospection, invited to give their opinion, and jointly produce the new design, contribute to construction site supervision, carry out small-scale maintenance work, and so on. These volunteers are most importantly engaged in the social integration process of the future tenants. SNL has 1,338 volunteers organized in 117 local solidarity groups. ${ }^{16}$ The association has more than 30 years' experience, during which time none of their projects has been blocked by an appeal from the local population (Primard \& Touati, 2015), a testament to inclusive and attentive processes of suburban renewal.

SNL is part of a national federation of such associations, FAPIL, ${ }^{17}$ that promotes social integration through housing, aiming to diversify the social housing stock. These associative actors often cooperate with private land-

15. “New Solidarities for Housing": http://www.snl-union.org/ (in French)

16. https://www.snl-union.org/nous-connaitre/presentation/ (in French)

17. http://www.fapil.net/ (in French) 
lords, with $77 \%$ of FAPIL's affordable housing being produced through the mobilization of the private housing sector. ${ }^{18}$ Furthermore, beyond associative actors, since 2000 traditional social housing organizations have also undertaken smaller scale projects; in that time, $95 \%$ of newly built social housing is considered to be small collective housing complexes, intermediary housing, or individual dwellings (Stébé, 2016). In 2010, a state study recommended that the private individual housing market and construction in empty areas of 'patchy' suburban land should be mobilized more effectively to provide social housing stock (Massin et al., 2010). These are all indications of the increasing engagement of the social housing sector in French suburban territory.

In Demark, the NGO Emergency Architecture \& Human Rights (EAHR) began a project in 2016 to renovate empty buildings and turn them into homes for refugees. This project considers the needs of refugees in synergy with local communities, often working within suburban municipalities. For example, the municipality of Odsherred housed 127 refugees in 2016 after renovating an abandoned nursing home. Similarly, in the city of Horve proposals have been made to invest in abandoned businesses, thus creating a strong link between housing and economic activities. With the arrival of migrants, the local government wanted to revitalize the town, which was gradually losing residents attracted by larger cities.

Residential subdivision as a potential affordable housing resource is now being explored by bottom-up initiatives through innovative solutions designed to increase successful integration. Although such practices are far from standard, they have productive elements for the reinvention of residential subdivisions. However, the citizen involvement that seems to be an integral part of such initiatives could prove a challenging prerequisite for the coherent implementation of such strategies across different territories.

\subsection{Reinventing professional practices}

Even though urban sprawl goes against the principles of sustainability, more than half of European households live in single-family houses (Eurostat,

18. http://www.fapil.net/wp-content/uploads/2017/12/Plaquette_2017_web.pdf (in French) 
2016), which intensify the contribution of housing to land consumption. There is a clear need to reinvent practices to counter this trend.

A review of the European press shows that homeowners are carrying out innovative experiments all over Europe. These often involve building extensions onto existing houses, either for the owners themselves or for rental. Some homeowners have also built annexes in their gardens from which to run a business, such as cafés or bakeries, ${ }^{19}$ but also medical practices. Architecture-Studio designed a clinic in the garden of two doctors living in a residential subdivision of Lagny-sur-Marne (France).$^{20}$ These private initiatives contribute to the renewal of neighborhoods by introducing services and local shops where only houses were previously found. However, such individual projects are often symptomatic of the lack of an overall project for the neighborhood and do not meet the current challenges concerning mobility, energy, environment, public space, social cohesion.

Changing professional views across Europe are also opening up another perspective on suburban renewal. The more recent projects described below show a growing interest in reinvesting in well-located urban spaces in metropolitan areas.

The first project is based on the principle of collective renovation. In Belgium, economic crisis hit the province of Limburg in 2014 caused by the closure of a large multinational company. One of the strategies the provincial government applied to tackle this crisis was to invest in the building industry by supporting projects that fell within its climate policies. One such project was the collective renovation of neighborhoods or housing blocks, mainly by reducing their energy consumption. The project was coordinated by the Belgian NGOs Stebo and DuboLimburg. Based in Genk (BG), Stebo is a social profit organization whose mission is to "create sustainable changes and improvements to the social and physical fabric of our society". ${ }^{21}$

19. https://www.estrepublicain.fr/edition-de-besancon/2017/04/29/mon-snack-dans-le-jardin, https://munchies.vice.com/fr/article/vvaznj/lhomme-qui-multipliait-les-pains-aufond-de-son-jardin, https://www.ladepeche.fr/article/2016/07/20/2387465-elle-installeun-snack-dans-son-jardin.html

20. http://www.architecture-studio.fr/fr/projets/lgn1/cabinet_medical.html

21. https://stebo.be/ 
DuboLimburg is a regional organization advising homeowners, municipalities and professionals within the field of sustainable building, renovation and living. ${ }^{22}$ Having observed that some Flemish households were facing financial difficulties in making their houses energy efficient, Stebo and DuboLimburg set up collective models of energy renovation in residential subdivisions. This reduces the investment for the homeowners, shortens the renovation period and takes away the administrative burden. Initial results clearly show that the collective aspect also strengthens the trust and solidarity among neighbors. The process starts with an application from a municipality. Then Stebo and DuboLimburg organize an information session, after which an architect and an energy consultant visit interested neighborhoods and contact all the residents. On the basis of the actual applications, they then contact a contractor. In their first year, the project was applied in four suburban neighborhoods in four towns, where 100 out of 566 houses were renovated. Since then, Stebo and DuboLimburg have applied the principle in more than ten neighborhoods. The region of Flanders turned it into a generic subsidy (called NeighborSubsidy) and town councils took on Stebo and DuboLimburg's coaching role. In parallel, other environmental projects are being developed in the Flemish suburban territory, such as cooperative renewable energy projects, ${ }^{23}$ revolving funds for energy renovation, pilot projects to remove (overabundant) infrastructure, ${ }^{24}$ etc.

In France, BIMBY (Build In My Backyard ${ }^{25}$ ) is currently being developed as an open source initiative to design, build, and collectively organize a new supply chain for housing production. This alternative aims to accommodate

22. https://www.dubolimburg.be

23. https://www.campinaenergie.be/

24. https://omgevingvlaanderen.be/ontharden

25. BIMBY (Build In My Backyard) is a collective brand registered (INPI $\mathrm{n}^{\circ}$ 3983105) as an open-source collaborative systemic project. The BIMBY concept encompasses any action aiming at housing production, under the following conditions:

- Without urban sprawl, on plots already built, without complete demolition of existing dwellings;

- Initiated by the inhabitant, in an architectural and landscape approach respectful of the neighborhood and of the local community common project;

- Orchestrated by local governments, in a process of territorial development federating and integrating the projects of the inhabitants;

- Without land speculation, with full transparency of the value and enhancement potential of inhabitants' real estate assets. 
new dwellings in the many private yards and gardens resulting from decades of urban sprawl. Since 2013, BIMBY has been tested and developed by professionals from many fields, committed to supporting willing homeowners, and then coaching them through projects to transform or adapt their properties. Some of these projects involve building new housing in gardens or backyards, thus directly targeting the formulation and validation of a new pragmatic, soft and collaborative solution to urban sprawl (Miet \& Le Foll, 2010). Considering both urban sprawl and the difficulty of developing existing neighborhoods with traditional planning tools, the BIMBY concept originated in research into a soft densification process that could be implemented without direct control over land resources. Soft densification is an alternative to greenfield development (the consumption of natural and agricultural land), or a hard densification process that requires more centralized land ownership. The method has been designed as a way to accommodate new residential units in the gardens of already developed areas of single-family dwellings with no need for a public or private developer to buy existing low-density homes and replace them with higher density ones (Le Foll \& Miet, 2013). Early BIMBY experiments reinstated urbanism as a real and direct service offered to the inhabitant, with BIMBY officers subsidized by local governments providing free help to homeowners who want to design and carry out their projects. So far, 3,000 households have taken part in BIMBY protocols tested in a wide range of urban areas, from villages with 1,500 inhabitants to towns of 30,000, and from urban areas with 95,000 inhabitants to regional clusters covering dozens of cities and home to more than 150,000 inhabitants.

BIMBY and Stebo are examples of a new professional sector in suburban development, underpinned by environmental sensitivities. These two companies pave the way for an accelerated spontaneous renewal, based on closer collaboration between institutions, professionals and homeowners and aiming at more efficient use of energy and urbanized space. These collaborations aspire to rebuild collective action around environmental issues through engaging and dynamic business processes.

Despite these new processes, transitioning from individual to general interest implies a complex shift in scale, and consequently, planning coherence is not always guaranteed. Indeed, relying on private initiatives could have 
negative consequences over time, ranging from "undersized parking, to the absence of public spaces and places of socialization, not to mention the disappearance of gardens and their social, landscape and ecological role" (Hanrot, 2015).

\subsection{Public action in the suburban context}

Public actors encounter difficulties when acting within already built-up areas. In France, Denmark and Belgium, ownership is a deep-rooted right that restrains public action. For this reason, public-led projects are usually carried out on undeveloped or vacant plots such as greenfields and brownfields. More recently, public action has applied new strategies to carry out new projects with homeowners.

In France, Councils for Architecture, Urbanism and Environment (CAUE) are active in this field. Indeed, more than twenty of these county-based organizations have produced educational documents, and organized site visits, participatory workshops with residents, conferences, and so on. For example, in 2013 the Haute Savoie CAUE capitalized on the BIMBY concept to evaluate the renewal potential of the region's residential subdivisions. The experiment led to an exhibition that showed local communities how controlled densification could enhance their living environment.

More recently, the French Ministry of Spatial Planning, Rural Affairs and Local Authorities set up a public platform called Lab périurbain (2016). This platform aims to identify and support innovative ongoing suburban projects, and provides a space for dialogue through a participatory democracy approach. More than 200 projects are currently being surveyed, covering a wide range of actions with diverse themes: mobility, digital, the elderly, economy and work, social housing, ecodistrict, agriculture, citizen participation, crafts, and so on. As well as this diversity, many of these projects involve innovative partnerships between professionals, associations, inhabitants and public institutions. For example, $L e V$ was conceived as an innovative cooperation space in the Jura region. It developed out of an original partnership between the owner of a building for rent and entrepreneurs looking for workspace. The building association brings together nearly thirty companies with various skills who share premises, communication and furniture. Recently, public subsidies have allowed the owner to delegate management to the building 
association, which enhances social life among entrepreneurs as a number of rules have been set and events and activities organized to facilitate the use of the cooperative space.

Similar experiences in Denmark are based on partnerships between residents, professionals, associations and public institutions. For example, the suburban area of Årslev/Sdr. Naeraa was affected by the closure of an industrial plant in 2010, which was an important economic resource for the area. In 2015, the municipality of Faaborg-Midtfyn (which falls under the Årslev administration) bought the factory and decided to rehabilitate it as a cultural and social center. The council contracted an organization, Givrum, specialized in revitalizing abandoned buildings, creating events (festivals, conferences) and developing participation processes. ${ }^{26}$ To transform the factory into a social center, Givrum set up a participation process involving events and workshops with citizens. This approach has proved to be a success, since the Polymeren now hosts many activities in spaces as diverse as a games café, a meeting room, a collective kitchen, a coworking space, a filmlab, specialist stores, a skateboard space, workshop spaces and a covered stadium.

Also in Flanders, innovative partnerships have emerged and are exploring how to sustain and/or introduce a range of services in suburban environments. One such experiment is taking place in Godsheide, a suburban town in the vicinity of the city of Hasselt. Currently Godsheide has a church, a school, a small care center, a community center, a youth center and two restaurants owned by two brothers who are no longer on speaking terms. The church is underused, the school and the care center have building plans and the youth center and community center are both surrounded by parking lots. There is no qualitative public space. From 2014 to 2024, Godsheide is predicted to double in size because of a series of new suburban developments currently being approved and implemented. Some residents expect that these developments will have a negative impact on the already problematic mobility situation, the undersized sewage system, the capacity of the services, and social cohesion. These neighbors formed an association, Unie Godsheide, ${ }^{27}$

\footnotetext{
26. https://givrum.nu/case/polymeren/

27. https://de-unie-godsheide.be/
} 
and began to organize social events, but also information sessions, futuring workshops and prototyping events. Throughout the process they develop future visions and draw up concrete projects, but also reconsider their current mobility and dwelling behavior. One of their projects is to promote a cooperation agreement between the church, the school, the care center, the youth center and the community center. In the initial stage they brought together the key actors from these organizations and explored ways of sharing facilities such as storage, bicycle parking, etc. However, they soon realized that the green space between all the buildings has much more potential. They discussed how to remove fences, change the orientation of the planned buildings towards this green space and coordinate its management. At the same time, a new community center is being developed, partly on private property, partly managed by private actors, but open to all residents. What started as a small citizen initiative has grown into a project with the assistance of participation professionals, and is now being implemented with the help of all the involved organizations and the city of Hasselt.

Even though residential subdivisions are dominated by private ownership, some institutions have successfully met the challenge of implementing collective projects in suburban areas. In order to support such projects, municipalities should provide and organize educational events, research actions, economic support for citizen initiatives and project leadership (De Blust et al., 2019), all of which could prove challenging in certain cases.

\section{Conclusion}

In urban planning, the result lies in the means rather than the end because there is no end... Jane Jacobs to her French translator Claire Parin in $1999 .{ }^{28}$

From a historical perspective, although the cultural and political contexts are not the same, the three European countries studied show how a massive

28. http://www.lemonde.fr/livres/article/2012/09/18/pour-une-ville-intense_1761865_3260. html? 
phenomenon such as suburbanization can be regarded as a European cultural model. The historical-political perspective reveals three major periods in the construction of residential subdivisions:

- An initial period of supported expansion in all three countries ran from the late nineteenth century to the early 1990s. This is the model of a prosperous and developed way of life.

- Between 1990 and 2010, the sustainable development debate identified negative externalities in this first model, causing it to fall out of favor.

- Sustainable development principles then took over and residential subdivisions began to be seen as spaces still under construction. The developments of the twentieth century are considered as preliminary stages to which other uses and other forms can be added.

As we have observed, the debates around sustainable development can be seen as informing suburban renewal initiatives. By becoming 'laboratory spaces' (Dodier 2012), the suburbs are considered as unfinished urban spaces where the model can be redrawn from a political, environmental and social perspective, but also from the point of view of architecture, urban planning and governance.

The diverse experiments described in the third section illustrate the variety of local stakeholders that can take part in such initiatives. Fertile collective action could leverage transformation of existing suburbs and improve them in a commonly agreed direction. Some of these initiatives advocate small incremental innovations, repeated and used by a great many, to transform the way cities are built and lived in. It is in this very sense that residential subdivisions are currently perceived as dynamic, transformable spaces which reveal contemporary changes in lifestyles and urban modes of production.

Part of these initiatives - referred to as 'massive small' - states that top-down policies should support incremental bottom-up initiatives by establishing conditions in which people's creative forces lead them collaborate in shaping and managing their living environment (Campbell 2011). Regardless of their respective forms, these initiatives introduce a radical break away from dominant approaches. As they are developed by citizens to answer shared 
concerns about societal issues by building on collective processes, these initiatives redefine productive norms and tasks, thus improving the resilience of local communities. Scalability opens up new perspectives for local governments to take action and sustain paradigm changes.

However, as raised at the end of each example, a number of challenges must be considered when discussing the renewal of residential subdivisions: What is the potential for alternative business structures, such as cooperatives, in renewal initiatives? What is the potential for civic participation in each case, and how can it be assessed? How can we ensure that the scaling up of the emerging professional sector produces coherent urban environments? Do local authorities have the capacity to organize such processes?

Whether professional, civic, private or public, a wide variety of actors can collectively learn and organize to contribute to the renewal of a given suburban space and to explore its potential.

\section{Acknowledgments}

The research discussed in this paper is part of the CAPA.CITY research project, funded by ERA-NET Cofound. For more information, see: https:// www.capa-city-ensuf.eu

\section{References}

Andersen, J. \& HovgaArd, G. (2003). Welfare and urban planning in transition: a Copenhagen case study. Roskilde University

Ascher, F. (1999). Métapolis: ou l'avenir des villes. Paris: Éditions Odile Jacob

Basiago, A. D. (1999) "Economic, social, and environmental sustainability in development theory and urban planning practice". The Environmentalist, 19, p.145-161

Bauer G. (1979). Un urbanisme pour les maisons. Paris: Editions 10/18

Bech-Danielsen, C. (2013): Suburban Development in Denmark. Paper presented on the NSBB Conference Suburbs - Transformation and Development, 17-19. Aalborg University 
Berger, M., Rougé, L., Thomann, S., Thouzellier, C. (2010). "Vieillir en pavillon : mobilités et ancrages des personnes âgées dans les espaces périurbains d'aires métropolitaines (Toulouse, Paris, Marseille)". Espace populations sociétés. Space populations societies, no 2010/1 (2010): 53-67. https://doi.org/10.4000/eps.3912.

Bonnet, F. (2016). Aménager les territoires périurbains et ruraux. Rapport remis au ministère du Logement, de l'Egalité des territoires et de la Ruralité.

CAMPbell, K. (2011). "Smart urbanism: Making massive small change". In Journal of Urban Regeneration \& Renewal, 4, pp. 304-311.

Castells, M. (1996). The Rise of the Network Society. Malden, Mass.: Blackwell Publishers

Chalas, Y., Dubois-Taine, G. (1997). La Ville émergente. La Tour d'Aigues: Éditions de l'Aube.

Charmes, E. (2015a). La ville émergente. Available at: http://www.citego. org/bdf_fiche-document-25_en.html (accessed 18 Feb. 2018).

Charmes, E. (2015b). L'entre ville. Available at: http://www.citego.org/bdf fiche-document-24_en.html (accessed 18 Feb. 2018).

Charmes, E. (2015c). La ville diffuse. Available at: http://www.citego.org/ bdf_fiche-document-23_en.html

Charmes, E. (2014). "La transformation des quartiers pavillonnaires en question". La revue foncière, novembre 2014, http://www.revue-fonciere.com/.

Chiodelli, F., Baglione, V. (2013). "Living together privately: for a cautious reading of cohousing". Urban research and practice, 7:1, pp.20-34, DOI: $10.1080 / 17535069.2013 .827905$

Clark, W. (2001). “A Transition Toward Sustainability”. Ecology Law Quaterly, University of California Berkeley, 27, nº 4: 102175.

DAMON, J. (2017). "Les Français et l'habitat individuel : préférences révélées et déclarées". SociologieS. Available at: https://sociologies.revues. org $/ 5886$

De Blust, S., Devisch, O. and Schreurs, J. (2019). "Towards a Situational Understanding of Collective Learning: A Reflexive Framework". Urban Planning, 4(1), 19-30.

De Decker, P. (2008). "Facets of Housing and Housing Policies in Belgium". Journal of Housing and the Built Environment, 23 (3): 155-171. 
De Decker, P., Dewilde, C. (2010). "Home-ownership and asset-based welfare: the case of Belgium". Journal of Housing and the Built Environment, vol.25, issue 2, p.243-262. https://doi.org/10.1007/ s10901-010-9185-6

De Decker, P. \& Meeus, B. (2013). De geest van suburbia. Maklu Uitgevers.

De Meulder, B., Schreurs, J., Cock, A., \& Notteboom, B. (1999). "Patching up the Belgian Urban Landscape". Consumption and Territory, OASE, (52), 78-113.

Dezès, M. G. (2001). La politique pavillonnaire. Paris: L'Harmattan.

DoDier, R. (2012). Habiter les espaces périurbains. Rennes: Presses Universitaires de Rennes.

Donzelot, J. (2009). La ville à trois vitesses: relégation, périurbanisation, gentrification. Paris: Éditions de la Villette.

Dragsbo, P. (2008). Hvem opfandt parcelhuskvarteret? Forstaden har en historie. Syddansk Universitetsforlag.

Driant, J. C. (2015). Les politiques du logement en France. Paris, La Documentation Française.

Dunham-Jones, E. (2011). Retrofitting Suburbia: urban design solutions for redesigning suburbs. New Jersey: John Wiley \& Sons, Inc.

European Environment Agency, (2016). Urban Sprawl in Europe. Joint EEA-FOEN report, 2016. https://www.eea.europa.eu/publications/urban-sprawl-ineurope.

Eurostat (2016). Housing statistics: type of dwelling. Available at: https://ec.europa. eu/eurostat/statistics-explained/index.php/Housing_statistics\#Type_of_ dwelling

Field, M. (2004). Thinking About Cohousing: The Creation of Intentional Neighbourhoods. London: Diggers and Dreamers Publications

GaARdmand, A. (1993). Dansk Byplanlægning, 1938-1992. Arkitektens forlag.

GuerRand, R.-H. (1987). "L'enfermement pavillonnaire". In Histoire de la vie privée. Tome 4, Tome 4, Paris: Seuil

Habitat Groupé-Solidaire, (2017). ASBL, coopérative, fondation, copropriété, CLT : les formes juridiques. Available at: https:// www.habitat-groupe.be/outils-methodologiques/les-differentes-formes-juridiques-de-lhabitat-groupe-solidaire/asbl-cooperative-fondation-copropriete-clt-les-formes-juridiques/

Hall, T. (1991). Planning Europe's Capital cities: Aspects of nineteenth-Century Urban Development. London: Routledge 
Hanrot, S. (2015). "Pour une stratégie de projet urbain participatif dans les quartiers pavillonnaires". In: Touati, A. \& Crozy, J. (eds.) La densification résidentielle au service du renouvellement urbain: filières, stratégies et outils. Paris, La Documentation Française.

Hanson, K.S., Hanson, C.S. (2004). The Cohousing Handbook: Building A Place For Community. Gabriola Island: New society press

Harris, R. (2013). "How Land Markets Make and Change Suburbs", in Keil, R. (ed.) Suburban Constellations, jovis Verlag, Berlin, 2013

Hesse, M., Siedentop, S. (2018). "Suburbanisation and Suburbanisms: Making Sense of Continental European Developments". Raumforschung Und Raumordnung | Spatial Research and Planning, 76(2), 97-108. doi:10.1007/s13147-018-0526-3

HiRT, S. (2007). "Suburbanizing Sofia: Characteristics of Post-Socialist PeriUrban Change". Urban Geography, 28, no 8: 755-80. https://doi. org/10.2747/0272-3638.28.8.755.

HurLey, A. K. (2019). Radical suburbs: experimental living on the fringes of the American city. Cleveland: Belt Publishing

Indovina, F. (1990). La città diffusa. Venice: Istituto universitario di architettura.

JENSEN, J. B. (2006). Fra nutidens til fremtidens parcelhuse. Center for fremtidsforskning.

KRIM, A. (1992). "Los Angeles and the anti-tradition of the suburban city". Journal of historial geography, vol.18, issue 1, p.121-138

KRISTENSEN, H. (2007). Housing in Denmark. Centre for Housing and Welfare - Realdania research. Future of Cities 51st IFHP World Congress

Kvorning, J., Ellefsen, K. O., Poulsen, P. S., Kørnøv, L., Nyboe, M., AnDERSEN, H. T., Groes, E. (2012). Baeredygtige forstceder: Udredning og anbefalinger fra Forstoedernes Tanketank. Naturstyrelsen \& RealDania

LAMBERT, A. (2015). “Tous propriétaires!”. L'envers du décor pavillonnaire. Paris: Seuil.

Le Corbusier (1971). La charte d'Athènes. Paris: Les éditions du Seuil.

Lefebvre, H. (1974). The Production of Space. Oxford: Basil Blackwell.

Lefèbvre, H. in Raymond, H., Haumont, N., Raymond, M-G. \& Haumont, A. (1966). L'habitat pavillonnaire. Paris: Institut de sociologie urbaine, Centre de recherche d'urbanisme Impr. du Centre de recherche d'urbanisme.

Lietaert, M. (2010). “Cohousing's relevance to degrowth theories". Journal of cleaner production, 18 , p. 576-580. 
Lind, O. \& Møller, J. (1996). Bag hækken - det danske parcelhus I lyst og nød. Arkitekten.

— (2014). Alletiders parcelhuse 1860-2012. Gyldendahl.

MAGRI, S. (2008). "Le pavillon stigmatisé. Grands ensembles et maisons individuelles dans la sociologie des années 1950 à 1970”. In L'année sociologique. Pp. 171-202

Marchal, H. \& Stébé, J-M. (2017). “Où en est le pavillonnaire”. In SociologieS. Consulté le 28 avril 2019. URL: http://journals.openedition. org/sociologies $/ 5880$

Marcus, C.C. (2000). "Site planning, building design and a sense of community: An analysis of six cohousing schemes in Denmark, Sweden, and the Netherlands". Journal of architectural and planning research, 17(2), p.146-163

Massin, I., Prevot, M., Tetart, J. M. (2010). Mission sur la production de logements sociaux en diffus, réalités et obstacles. Available at: http://www.hlm.coop/ressources/all/10603

McCamant, K. M., Durrett, C., Hertzman, E. (1994). Cohousing: A Contemporary Approach to Housing Ourselves. Berkley: Ten speed press.

McCamant, K. M., Durrett, C. (2011). Creating Cohousing: Building Sustainable Communities. Gabriola Island: New society press.

Merlin, P. \& Chony, F. (1988). Dictionnaire de l'urbanisme et de l'aménagement. Paris: Presses Universitaires de France.

Miet D. \& Le Foll B. (2010). "Faire émerger la ville durable des tissus pavillonnaires". Available at : http://bimby.fr/content/ faire-\% $\%$ C3\%A 9 merger-ville-durable-tissus-pavillonnaires-existants

— \& LE Foll, B. (2013). "Construire dans mon jardin et résoudre la crise du logement. Cinq idées-clés pour comprendre la filière BIMBY", in Métropolitiques, URL : https://www.metropolitiques.eu/Construire-dans-mon-jardin-et.html, consulté le 28.07.18

Miljø- og Energiministeriet Landsplanafdelingen, (2000). Planhistoriske forudsætninger for rummeligheden til bolig- og erhvervsbyggeri. København, januar 2000

Newman, P., Kenworthy, J. R. (1999). Sustainability and Cities. Overcoming Automobile Dependence. Washington: Island Press.

Phelps, N. A. \& Wu, F. (eds.) (2011). International Perspectives on Suburbanization - A Postsuburban World? Palgrave Macmillan. 
Pinson, D. (2017). “Le pavillon n'est pas la maison”, SociologieS, Dossiers, Où en est le pavillonnaire? Available at : http://journals.openedition. org/sociologies/5891

PIron, O. (2011). "Vous avez dit urbain". Études foncières, no $153: 4-5$.

Primard, E., Touati, A. (2015). La construction de logements sociaux en densification douce par les micro-bailleurs: le cas de Solidarités Nouvelles pour le Logement. In: Touati, A. \& Crozy, J. (eds.) La densification résidentielle au service du renouvellement urbain: filières, stratégies et outils. Paris : La Documentation Française.

PUCA (2011). Du périurbain à l'urbain, appel à consultations de recherche. http://www.urbanisme-puca.gouv.fr/du-periurbain-a-1-urbain-a479. html.

- (2014-2017). Densification douce. Intérêts, limites, opportunités. Paris: PUCA, http://www.urbanisme-puca.gouv.fr/vers-des-politiques-publiques-de-densification-et-a275.html.

Puissant, J. (2008). “L’exemple belge : l'habitat privé, la maison individuelle l'emportent sur l'habitat collectif". Revue du Nord, vol. 374, no. 1, pp. 95-116.

Richner, M. \& IbSen, M. E. (2016). Fortcetning af danske parcelhusområder. Master Thesis Ålborg University, Department of Planning.

Touati, A. (2015). "La densification douce des tissus pavillonnaires : quelles pratiques pour quels enjeux?" In: Touati, A. \& Crozy, J. (eds.) $L a$ densification résidentielle au service du renouvellement urbain: filières, stratégies et outils. Paris : La Documentation Française.

— \& Crozy, J. (eds.) (2015). La densification résidentielle au service du renouvellement urbain: filières, stratégies et outils. Paris, La Documentation Française.

Tummers, L. (2015a). "Understanding co-housing from a planning perspective: why and how?" Urban Research \& Practice, 2015, Vol. 8, No. 1, 64-78, http://dx.doi.org/10.1080/17535069.2015.1011427

- (2015b). "The re-emergence of self-managed co-housing in Europe: A critical review of co-housing research". Urban Studies, 1-18, DOI: $10.1177 / 0042098015586696$

Tzaninis, Y., Boterman, W. (2018). "Beyond the urban-suburban dichotomy: shifting mobilities and the transformation of suburbia". City, vol.22, no.1, pp. 43-62. https://doi.org/10.1080/13604813.2018.1432143

Sieverts, T. (2003). Cities without cities: An interpretation of the Zwischenstadt. London : Spon Press. 
STÉBÉ, J. M. (2016). Le logement social en France. Paris: Presses Universitaires de France.

Stevenson, D. (2003). Cities and urban cultures. Maidenhead: Open University Press.

Sverrild, P. (2016). Periurban Phase and Sphere. PhD dissertation. Aalborg University

VAN DE WeIJer, M. (2014). Reconfiguration, Replacement or Removal? Evaluating the Flemish Post-War Detached Dwelling and its Part in Contemporary Spatial Planning and Architecture. Unpublished $\mathrm{PhD}$ Thesis, Hasselt University - KULeuven.

VANIER, M. (2011). "La périurbanisation comme projet", in Métropolitiques, Available at: https://www.metropolitiques.eu/La-periurbanisation-comme-projet.html

Williams, J. (2005). "Designing Neighbourhoods for Social Interaction - the case of Co-Housing”. Journal of Urban Design, 10(3), p.195-227 
